\title{
How does it feel to be evaluated? A systemic look at postgraduate students
}

\author{
Deise V. P. Carvalho ${ }^{1}$, Marli A. Ranal ${ }^{* 2}$, Clesnan Mendes-Rodrigues ${ }^{3}$ \\ ${ }^{1}$ Deise Carvalho Psicologia e Consultoria, Uberlândia, Minas Gerais, Brazil \\ ${ }^{2}$ Instituto de Biologia, Universidade Federal de Uberlândia, Uberlândia, Minas Gerais, Brazil \\ ${ }^{3}$ Faculdade de Medicina, Universidade Federal de Uberlândia, Minas Gerais, Brazil
}

Received: May 23, 2019

DOI: $10.5430 /$ ijh.v5n2p49
Accepted: July 30, 2019

Online Published: August 7, 2019

\begin{abstract}
The structural constellation, applicable to education, was used to test the hypothesis that postgraduate students do not have difficulties to be evaluated. To test this hypothesis, the WHOQOL-BREF questionnaire (World Health Organization Quality of Life Instrument abbreviated) was applied to 36 students of the Postgraduate Program in Agronomy of the Universidade Federal de Uberlândia, on the first and last days of the school semester of 2017. Half of these students spontaneously accepted to participate in the constellation and responded to two systemic questionnaires, one at the beginning and the other at the end of the semester. During the first month of classes, the 18 students were submitted to the nine squares of the structural constellation technique. At the beginning of the semester, the two groups presented the same quality of life profile. After the constellation, the desire of the 18 students to increase their comfort during the assessments was achieved. In addition, the constellation improved the quality of life of the treated group, regarding the psychological and the environment domains. Another important aspect was the positive correlation between the desire of greater comfort during the assessments and the social domain, before the constellation, and with the psychological domain after the constellation. Knowing that the two groups were initially equal and that the quality of life was improved for the group that participated in the constellation, we hope that this type of therapy can help students to look at the evaluation process with more self-confidence and tranquility, which may improve their academic performance.
\end{abstract}

Key Words: Constellation therapy, Holistic health, Holistic therapy, Quality of life, Systemic education

\section{INTRODUCTION}

In 80's, when Postgraduate Programs were in sharp rise and expansion, a publication came out in a local newspaper titled "A síndrome do Tesano" (the syndrome of the thesis writer). The article was read and drew good laughs from members of the academic community, since it was a satire of the behaviour of the postgraduate students. The symptoms and the sequence were similar among the students, without any of them describing them to their colleagues. From the symptoms, it was possible to know if the postgraduate students were only attending disciplines, if they were doing the bibliographical research to assemble their project, if they were collecting data, which is subject to many eventualities; if they were writing the introduction, material and methods, results or if they were in the most difficult and confusing part, which is the discussion of the results obtained. There was still the emotional discomfort (distress) in the preparation of the qualification class and finally the defence of the

\footnotetext{
*Correspondence: Marli A. Ranal; Email: marliranal@gmail.com; Address: Instituto de Biologia, Universidade Federal de Uberlândia, Avenida João Naves de Ávila 2121, Uberlândia, MG 38400-902, Brazil.
} 
dissertation or thesis, not mentioning those who were being funded by research organs and who needed to deliver their semi-annual reports for the maintenance of the scholarship.

Like all good satire, the manifestations of the ones who were initiating their research were described in an exaggerated way. To make sure their data were safe, the postgraduate students took their notes into the bathroom, afraid that they would disappear or that someone would steal them. Major accidents occurred as the burning of a famous building in São Paulo, Brazil, which converted all the data of a thesis to ashes, as well as others that were not disclosed in the media. Until today, each stage of the life of postgraduate students have very large similarities, even though they don't talk to each other about their emotional discomfort (situations that involve anxiety and sometimes anguish, generating suffering, distress and also other psychological pathologies). All this is triggered by pressures from the academic-scientific environment, which requires unrealistic quantity and quality in relatively low deadlines.

Although four decades have passed since the first official evaluation of the Brazilian Postgraduation conducted by the Coordenação de Aperfeiçoamento de Pessoal de Nível Superior (CAPES) in 1978, ${ }^{[1]}$ which established the minimum requirements to be achieved to ensure the training of Masters and Doctors with quality, the situation has not changed much. Although today the risk of losing one's work is practically zero thanks to the help of computers, the postgraduate students face new problems such as the risk of plagiarism if confidential files of ongoing research are accessed without authorization. However, the larger issue is, as Indjaian states, ${ }^{[1]}$ the productivist logic that has established itself with the competition among Postgraduation Programs, since it leads to stresses within the scientific community.

Official data of the Ministry of Science and Technology showed that the number of Masters and Doctors in Brazil went from 26,000 in 2001 to about 53,000 in 2010. ${ }^{[2]}$ This growth, pushed by the research funding agencies, has led to stressors that were studied by the author, from a sample of 2,157 postgraduate students enrolled in more than 100 Postgraduate Programs of 66 Brazilian Institutions. The author used the Perceived Stress Scale (PSS) as an evaluation tool. The mean total stress of the sample was 29.1, in a scale of 56 possible points, being higher in females. According to the author, this value obtained for Brazilian students exceeded the recorded stress value for Indian, American and Nepali university students.

Eight main stressors, including the internal pressure for good performance (self-recovery), the demand of studies on other aspects of life, the external pressure on the completion of the course, the possibility of not achieving the performance expected by the examining board, financial issues due to studying part or full time, the time to complete the dissertation or thesis, the meeting of deadlines and the possible disappointment regarding the professional insertion in the labour market were identified by Faro. ${ }^{[2]}$ The financial question draws attention, because as Valadares et al. mention, ${ }^{[3]}$ the common-sense present in society is that postgraduate studies are not considered work.

A high level of stress negatively affecting academic performance was also detected in students of the Brazilian Postgraduate Programs in Accounting Sciences, based on the PSS instrument. ${ }^{[4]}$ It is possible to see that stress has increased over the years in several courses. Around $41 \%$ of the students of the Master's degree in Health Sciences presented stress, with women being most vulnerable to it, according to the Stress Symptoms Inventory for Adults of Lipp. ${ }^{[5]}$ Approximately $59 \%$ of 140 postgraduate students from the Universidade Federal do Rio de Janeiro who agreed to participate in the survey presented stress according to the same Inventory. ${ }^{[6]}$ Approximately $76 \%$ of the 49 Master's degree students of Veterinary Sciences evaluated by the same instrument presented stress, with a predominance of the phase of resistance and psychological symptoms. ${ }^{[7]}$ In the lato sensu postgraduation in Nursing, the Inventory pointed out that $77 \%$ of the students presented stress, most of them in the resistance phase, with a predominance of physical symptoms. ${ }^{[8]}$

The stress process has three phases, including the alert, the resistance and the exhaust. ${ }^{[9]}$ The alert phase consists of biochemical reactions of the organism, which recognizes the stressor and prepares to fight or escape; the resistance occurs when the stressor remains for prolonged periods, requiring the physiological adaptation from the organism, with an overload of the endocrine and immune system. The damage caused by the stress does not disappear, so the body has no chance to recover and remains in a state of alert. Finally, the exhaustion phase is when stress exceeds the possibility of the organism to live with it and the body can no longer respond to demands. Reactions are harmful and can lead to serious illnesses. This three-phase model was modified by Lipp ${ }^{[10]}$ by adding the almost exhausting phase, characterized by a weakening of the organism by failing to adapt or resist the stressor.

Of the 73 students regularly enrolled in a Postgraduate Nursing Program in Rio de Janeiro, Brazil, 60\% of the Masters and Doctoral candidates participated in the study of Ferreira et al. ${ }^{[11]}$ who used a sociodemographic survey and the Brief Stress \& Coping Inventory-Brief SCI published in 1999 by 
the International Stress Management Association. The results obtained by the authors showed that $70 \%$ of the students considered themselves stressed, with $34 \%$ at high risk of getting sick by stress and $30 \%$ with a moderate level of illness, highlighting the demand to meet deadlines as one of the important stressors. The Burnout syndrome, assessed by the Maslach Burnout Inventory TM-Student Survey (MBI-SS), was detected in Nursing Postgraduate students. ${ }^{[12]}$ Galdino et al. ${ }^{[12]}$ identified that $69.8 \%$ of the students had high scores in emotional exhaustion, $27 \%$ had high depersonalization, $24.8 \%$ had low academic efficacy and $11.6 \%$ had an indicative for Burnout syndrome.

The stress indices in postgraduate students were worrying both in Brazil and abroad. ${ }^{[6]}$ In addition to deadlines, the requirement for publications constitutes one of the main sources of stress in the academic environment. ${ }^{[13]}$

Even though the bibliographical research presented here is small because this work is not a review of the subject, and despite the differences in assessment instruments, areas of knowledge and Institutions, it can be seen that in 2007 the number of students stressed was around $40 \%$ and in 2013 it exceeded $70 \%$. The tendency for the number of postgraduate students with stress to increase can be verified, and this is a consequence of the demands of the Research and Postgraduate Institutions due to the increase in the number of laboratories and Postgraduate Programs; however, without a direct and proportional increase in the maintenance and costing funds. In addition, the labor market began to require highly skilled and professionals with greater resistance to internal and external pressures. ${ }^{[14]}$ This makes the postgraduate student a professional in training with demands that are equivalent or higher than those of professionals who are already incorporated in the labor market and, therefore, something needs to be done.

With the students of the Postgraduate Program in Agronomy from the Universidade Federal de Uberlândia (UFU), Brazil, the story repeats itself and it is to this audience that this work has been devoted. The Postgraduate Program in Agronomy was approved by Resolution No. 07, of December 21, 1999, by the University Council of the UFU. ${ }^{[15]}$ The Master's Program began its activities in March 2000 and the Doctorate Program in March 2007. In the four-year evaluation disclosed in 2017, the above mentioned Program (Master and Doctoral) was recognized by CAPES with score 5, on a scale ranging from 1 to $7 \cdot{ }^{[16]}$

Since the year 2000, during the implementation of the Program, students have shown difficulties, both as evaluatees and as evaluators, either in the presentation of seminars in disciplines, in the elaboration of reports or during the de- fence of their work (personal observation). This behaviour is typical of the postgraduate students, regardless of the Program. The stress triggered during these activities, in which the postgraduate students are exposed to a particular audience, often compromises their performance. Therefore, the null hypothesis that arises and has been tested, is that the postgraduate students have no difficulty to be evaluated and the alternative hypothesis is that these students have difficulty to be evaluated, remembering that the assessments are at the heart of every Academic and scientific process. The reason for this difficulty cannot always be detected with assertiveness, but in any case, the students can be assisted to solve their problem or problems, since the University relies on specific sectors within the Psychological, Medical and Social Assistance sectors to meet demands related to psychological, physical health or social problems.

To test these hypotheses, the technique used in this study was based on systemic thinking, whose support theory goes back to the therapeutic work of Virginia Satir, a psychotherapist and one of the founders of family therapy, called family sculpture; to the psychodrama of Jacob Moreno, graduated in medicine and psychiatry, and its psychotherapeutic applications; to the relationship therapy of Ivan BoszormenyiNagy, whose greatest contribution was the scientific research and the description of the systemic entanglements, caused by invisible loyalties; ${ }^{[17]}$ to the family constellation of Bert Hellinger, which is based on problem solving causing the person to become observant of their system, ${ }^{[18-21]}$ in this case, the academic and research system; and the structural constellation, idealized by Matthias Varga von Kibéd and Insa Sparrer. ${ }^{[22]}$

The work of Ivan Boszormenyi-Nagy allowed him to conclude that relationships are determined by an existential dynamic of connections he called invisible loyalties. His work brought the notions of loyalty, the balance between giving and receiving, merit and law, aspects of the relationship that are not restricted to a person but are multipersonal and transgenerational. All of these notions allowed the development of contextual therapy. In his vision, the essential element of the encounter between people is the ethics of the relationship that can be seen in the form of justice, fairness and mutual responsibility, thus allowing the trust between them to emerge. Information on these theories can be accessed at Franke-Bryson. ${ }^{[17]}$ Interesting is the observation made by the author about this therapy, which is more ethical than psychological, about transgenerational invisible loyalties. Injustices that are not resolved at the moment happen are distributed by a "intrinsic transgenerational tribunal" for future generations, taking into consideration a type of counting of merits and demerits, and this therapy brings the balance between the 
two things. In addition, the author comments, the people entangled in the system are incapable of intervening logically to separate themselves from it, because the origin is not in their biography, but in general, in previous generations. Entanglement can be identified based on symptoms that cannot be treated biographically and resist therapeutic interventions so that, in some way, the current generation can remember, even if unconsciously, the difficulties of past generations. According to Franke-Bryson ${ }^{[17]}$ both, Boszormenyi-Nagy and Moreno, call attention to the ethical dimension of the responsibility each person has to the human species as a whole.

Despite the focus of this work being associated with the academic system, the family system is the basis of each person and cannot be disconnected, because it is from this system that all people obtain their resources to be inserted in society. It is from this system also that the person brings the memory, maintained genetic and epigenetically, to face or escape the limiting factors of their physical and emotional survival (see principles of epigenetic in Lipton ${ }^{[23]}$ ).

When it comes to entanglement, Franke-Bryson ${ }^{[17]}$ refers to the existence of a predictable regularity of certain repetitive events in families, generation after generation, expressed as physical or behavioural patterns that have an impact on family components, without the person being aware, unless the first disorders, mental or somatic, appear. According to Boszormenyi-Nagy's words, this inheritance is like a tacit ethical contract with the justice of transgenerational solidarity. According to Franke-Bryson, ${ }^{[17]}$ this fact, before the work of Boszormenyi-Nagy, had not been taken into consideration in psychology.

The terms family sculpture, family reconstruction and family constellation are often used as synonyms, because they refer to a method in which people from other systems, called representatives, are configured spatially to represent elements of the system under study or in a therapeutic process. ${ }^{[17]}$ The formed configuration represents the inner image that the person has of his/her own system and provides elements to the observers, whether they are therapists, the family or the person involved, about the analyzed system. The information obtained in the structural constellation, observing this spatial configuration, shows the type of relationship that exists between the members and the functional structure of the system, with its resources and entanglements. During the systemic exercises, one can understand that they have internal and external resources that are at their disposal for problem solving. This gives power and autonomy to the people who come to look at their system as a source of resources and not of problems, because their ancestors were able to figure out how to solve events and left the solution for their descendants, as is known in epigenetic inheritance. ${ }^{[23-25]}$

The basic assumption of systemic therapies is that all people belong to a system, whether family, business, academic or other. It is important to highlight that in the systemic view, the living and the dead belong to the family system. ${ }^{[20]} \mathrm{Sim}$ ilarly, this is also valid for organizations, ${ }^{[26]}$ which include the people who work and those who withdrew from them, by reason of layoffs or deaths, but who contributed to their growth and survival. If everyone belongs, everyone occupies a certain place, from the founders of the system (organizations) and the ancestors (families) to the younger members, that is, every system has a hierarchy, either order of arrival, as in the family systems, ${ }^{[19,20,27,28]}$ or objectives, in the case of organizational systems. ${ }^{[26]}$ In organizations, the person who strives for the survival of the system or creates its structure occupies the first place in the hierarchy; the one who takes care of the internal development of the system occupies the second place and so on. ${ }^{[26]}$ In addition, everyone must have balanced relationships, so that no member receives what they do not need or gives more than they have. There is a need for the individuals to balance their relationship, that is, they need to give back something equivalent to what they received in order to establish a positive exchange or total exchange with the others. ${ }^{[20,27-29]}$ This only does not occur in the relationship between parents and children where, according to Hellinger's view, there is no way to return or compensate the life that came through the parents, because this is the natural flow over the generations. ${ }^{[21]}$ In this relationship, children can achieve equilibrium in another way, passing what they received from their parents to their own children or doing things of equivalent importance to other people. ${ }^{[19,20]}$ If there is a breach of any of these assumptions, the belonging, the hierarchy and/or the balance for some reason, there will always be some form of attempted compensation and this ends up destabilizing the system and affecting all of its components. ${ }^{[19,20]}$ Where there is such a breach, this technique, the constellation, has helped re-establish the balance in the system.

An important fact for Brazil is that the family constellation appears on the list included in the National Policy of Integrative and Complementary Practices, recently approved by a specific legislation (Portaria No. 702, of March 21, 2018) of the Health Ministry. ${ }^{[30]}$ This regulation strengthens the use of the technique in different systems, whether educational, private, state, prison, health, judicial, therapeutic, among others.

Based on this theory, the general hypothesis that was tested with this study was that the difficulty the postgraduate stu- 
dents have of being evaluated can be traced back to some unresolved difficulty within their system of origin. Probably the demand made by teachers and counsellors triggers the memory of previous stressors, experienced by the students themselves in previous phases of their life or by ancestors in their family system, generating the same physiological responses and that need to be recognized so that they can be better managed. The adopted constellation model allows the persons to get a solution image for the inner image that they have of their problem.

The expected result with this work is that the main objective of the demands and assessments be achieved with minimal stress. The demands and assessments are necessary and aim to develop the ability to meet deadlines and improve the students' critical capacity to evaluate their own work and that of colleagues, because this is part of the quality control of teaching, research and technology. This is an activity present in the life of a researcher or teacher of higher education and which is based on the ability to make and receive criticism in the sense that their project or their work can be improved to meet the principles of the scientific method, the demands of the company financing the activity and the social and technological requirements.

\section{MeTHODS}

\subsection{Study scenario}

In one of the general disciplines of the Postgraduate Program in Agronomy, a therapeutic intervention and support to students was proposed to improve not only their quality of life, but also their perceived quality of life using the WHOQOLbref questionnaire ${ }^{[31,32]}$ (World Health Organization Quality of Life Instrument abbreviated) and the method of structural constellations, with special focus on solutions. ${ }^{[17,22]}$ This study is an account of the assessments obtained. Therefore, this is an analytical descriptive study with a quantitative approach.

The proposal was approved internally by the Postgraduate Program in Agronomy, UFU, Brazil, being presented to students who could voluntarily choose to participate in the project, by submitting to the constellation and answering the questionnaires, or just answering the WHOQOL-bref questionnaire. As mentioned, participation and choice were spontaneous and everyone was free to leave the study at any time. Students interested in participating were accepted, with no inclusion and exclusion criteria. All signed an Informed Consent Form and released data usage so the results could be disclosed without their personal identification. In this sense, no data referring to each of the constellations will be presented here, to avoid the risk of identifying the students.

Published by Sciedu Press

\subsection{Sampling and evaluation tools}

A convenient, purposive and voluntary nonprobability sample of 36 students of the Postgraduate Program in Agronomy from the Universidade Federal de Uberlândia, Minas Gerais, Brazil responded to the quality of life questionnaire (WHOQOL-bref) ${ }^{[32-34]}$ at the beginning (see MendesRodrigues et al. ${ }^{[35]}$ ) and at the end of the first semester of 2017. Half of them, those who spontaneously accepted to be submitted to the constellation, also responded to two systemic questionnaires, one at the beginning and one at the end of the semester. The constellations occurred during the first month of the class semester.

As the interest in this work was to evaluate the increase or decrease in the quality of life of the students during the semester, for each of them the deviation of each variable of the WHOQOL-bref domains considered was calculated (subtraction of the value of each domain at the end of the semester from the value of the same domain at the beginning of the semester).

The profile of the students was analyzed by MendesRodrigues et al. ${ }^{[35]}$ The authors stratified the data into two groups, those who participated and those who did not participate in the constellation. The same criterion was adopted for the present study.

From a systemic point of view, during the interview that directed the constellation, general information about the family constitution and aspects related to the assessments was collected only from the 18 students who were submitted to the constellation. The common question to these 18 students, asked before and after the constellation, was as follows - "On a scale from zero to 10 , where zero is the most uncomfortable situation to be evaluated and 10 the most comfortable, how do you feel today?" This is a scale question, typical of the techniques of the structural constellation. ${ }^{[22]}$ This question will be referred to in the remainder of the work as the comfort scale, which was evaluated pre and post constellation. A second question was asked during the initial interview to know the student's desire for progress regarding this issue. "If the constellation works for you, what value, on the same scale, would you like to achieve, in the sense of being comfortable with the evaluation process?" This question will be referred to in the remainder of the work as the expected comfort scale by the students after the constellation.

\subsection{Place of application of questionnaires and perfor- mance of systemic exercises}

The application of the questionnaires and the realization of the systemic exercises took place within the Universidade Federal de Uberlândia, in one of the classrooms of the 
Umuarama Campus.

\subsection{Technique used during constellations}

The technique adopted for the structural constellations was the so-called nine squares, adapted from the 12 squares described by Sparrer. ${ }^{[22]}$ This technique is suitable for analyzing different life contexts that are entangled or overlapping. By having in its core the principles of mathematical logic, the technique helps the persons to organize the different aspects of their life. They must treat these aspects in their appropriate time and place. As each student brings with them family issues that mix with academic issues, this generates more tension than if each aspect is resolved within its specific environment. This technique allows the students to become observant of their relationships, facilitating the discovery of solutions.

Spatially, a representative of the person to be treated is in the center of the nine squares. On the right, the persons have issues related to their external world, on the left, issues related to their internal world, in front, issues related to their future and behind, those related to their past. When there are inversions in these positions, it is the responsibility of the therapist to intervene in such a way that the person can reposition the issues, reconstellating them into their proper time and place. This minimizes stress and provides resources for the person to get out of their entanglement or overlapping contexts and find the right solution for every aspect of their life.

Given the technique of the constellations with representations, the work counted on the presence of systemic therapists, initially made available in semicircle. They represented, by choice of each student submitted to the constellation, their Focus (the part of themselves who wanted to look at their issue), their issue, their objective, their resources and context elements of the issue.

\subsection{Statistical analysis of the data}

The statistical analysis of the collected data was performed using the SPSS 20 software, with a significance of 0.05 . The Chi-square test of independence, Exact Fisher test, ShapiroWilk test for normality, Student $t$ test, paired Wilcoxon test (for the comfort scales to be evaluated) and Spearman correlation for each specific comparison were used. Multiple linear regression was also used by the least squares method, with selection of variables by the backward method (probability of entry and exit of the model at 0.05 ). The predictive variables chosen were the marital status (with or without a partner), presence of children, remuneration, scholarship, postgraduate level, project choice phase, discipline study phase, data analysis phase, bibliographical research phase, age and mean level of satisfaction with postgraduation. These variables were used to predict the deviations in the quality of life domains and were selected because they presented significant results in some domains of quality of life of the same students at the beginning of the semester (see Mendes-Rodrigues et al. ${ }^{[35]}$ ) or because they had generated profiling differences in the two groups. In this type of analysis, the constant represents the mean value without interference from the predictive variables and the $\mathrm{Bi}$ is the $i$-th estimation of the linear regression model parameter that represents the negative or positive effect of the predictive variables in the variable of interest, in this case, the deviation from the domains of the WHOQOL-bref.

\section{RESULTS}

For the postgraduate students evaluated, there was a predominance of women (52.78\%), Brazilian citizens (97.22\%), without partner $(52.78 \%)$, young people (mean $=29$ years; median $=27$ years), without children $(80.56 \%)$, who lives with someone $(83.33 \%$; average $=2.09$ people per residence) and which are, on average, in the third semester and attending disciplines (94.44\%) (see Table 1). Most have some type of self-sufficiency (work or scholarship), whereas only 27.8 do not.

The profile of the postgraduates who were constellated and those who were not showed some differences. Those who were without partner, childless, attending Master's, without paid work, but with scholarship chose to participate in the constellation. Those who were with partner, childless, attending PhD's and with paid work preferred not to participate in the constellation. For the other variables, the profile was the same for the two groups.

In relation to the satisfaction in the choice of the University, the Program, the research line, the project and the advisor, regardless of the group, the averages were equal to or greater than 7.97, with no difference between the two groups. Therefore, the change in the quality of life of the students after the constellation is not related to these variables.

A positive mean deviation, significantly different from zero for the variable environment domain (mean $=4.88)$, indicated an improvement in the quality of life of the students regarding this item, after the constellation (see Table 2). Comparing the two groups, the students who were submitted to the constellation also presented higher mean deviations in relation to the psychological domain compared to the group that was not constellated $(4.69$ versus $-3.75, p=.023)$. For the other domains of the questionnaire there was no difference between the two groups. 
Table 1. Profile of 36 students of the Postgraduate Program in Agronomy - UFU, 2017; 18 constellated and 18 non-constellated

\begin{tabular}{|c|c|c|c|c|c|}
\hline Factor & Stratum & $\begin{array}{l}\text { Non-constellated } \\
\text { group \% (n) }\end{array}$ & $\begin{array}{l}\text { Constellated } \\
\text { group \% (n) }\end{array}$ & General \% (n) & Statistic ( $p$-value) $)^{\#}$ \\
\hline \multirow{2}{*}{ Gender } & Male & $61.11(11)$ & $33.33(6)$ & $47.22(17)$ & \multirow{2}{*}{$\chi^{2}=1.72(.182)$} \\
\hline & Female & $38.89(7)$ & $66.67(12)$ & $52.78(19)$ & \\
\hline \multirow{2}{*}{ Nationality } & Other & $0(0)$ & $5.56(1)$ & $2.78(1)$ & \multirow{2}{*}{$(1.000)$} \\
\hline & Brazilian & $100.00(18)$ & 94.44 (17) & $97.22(35)$ & \\
\hline \multirow{2}{*}{ Marital status } & Without partner & $33.33(6)$ & $72.22(13)$ & $52.78(19)$ & \multirow{2}{*}{$\chi^{2}=4.01(.045)$} \\
\hline & With partner & $66.67(12)$ & $27.78(5)$ & $47.22(17)$ & \\
\hline \multirow{2}{*}{ Children } & Without children & $61.11(11)$ & $100.00(18)$ & $80.56(29)$ & \multirow{2}{*}{$(.004)$} \\
\hline & With children & $38.89(7)$ & $0(0)$ & $19.44(7)$ & \\
\hline \multirow{2}{*}{ Lives with someone } & Alone & $16.67(3)$ & $16.67(3)$ & $16.67(6)$ & \multirow{2}{*}{$(1.000)$} \\
\hline & With someone & $83.33(15)$ & $83.33(15)$ & $83.33(30)$ & \\
\hline \multirow{2}{*}{ Level (degree) } & Master & $33.33(6)$ & $83.33(15)$ & $58.33(21)$ & \multirow{2}{*}{$\chi^{2}=7.31(.007)$} \\
\hline & $\mathrm{PhD}$ & $66.67(12)$ & $16.67(3)$ & $41.67(15)$ & \\
\hline $\begin{array}{l}\text { Self-sufficiency (work } \\
\text { or scholarship) }\end{array}$ & Yes & $72.22(13)$ & $72.22(13)$ & $72.22(26)$ & $\chi^{2}=0(1.000)$ \\
\hline Paid work & Yes & $55.56(10)$ & $16.67(3)$ & $36.11(13)$ & $\chi^{2}=4.33(.037)$ \\
\hline Scholarship & Yes & $16.67(3)$ & $55.56(10)$ & $36.11(13)$ & $\chi^{2}=4.33(.037)$ \\
\hline Absence of leave & Yes & $16.67(3)$ & $0(0)$ & $8.33(3)$ & $(.114)$ \\
\hline $\begin{array}{l}\text { Phase - choosing } \\
\text { research project }\end{array}$ & Yes & $44.44(8)$ & $22.22(4)$ & $38.89(12)$ & $\chi^{2}=2.92(.087)$ \\
\hline $\begin{array}{l}\text { Phase - attending } \\
\text { disciplines }\end{array}$ & Yes & $94.44(17)$ & $94.44(17)$ & $94.44(34)$ & $(1.000)$ \\
\hline $\begin{array}{l}\text { Phase - mounting } \\
\text { experiments }\end{array}$ & Yes & $38.89(7)$ & $61.11(11)$ & $50.00(18)$ & $\chi^{2}=1.00(.317)$ \\
\hline $\begin{array}{l}\text { Phase - analysing } \\
\text { experiments }\end{array}$ & Yes & $38.89(7)$ & $66.67(12)$ & $52.78(19)$ & $\chi^{2}=1.78(.182)$ \\
\hline $\begin{array}{l}\text { Phase - doing } \\
\text { statistical analysis }\end{array}$ & Yes & $22.22(4)$ & $33.33(6)$ & $27.78(10)$ & $\chi^{2}=0.14(.710)$ \\
\hline $\begin{array}{l}\text { Phase - seeking } \\
\text { theoretical framework }\end{array}$ & Yes & $33.33(6)$ & $33.33(6)$ & $33.33(12)$ & $\chi^{2}=0.00(1.000)$ \\
\hline $\begin{array}{l}\text { Phase - preparing for } \\
\text { qualifying exam }\end{array}$ & Yes & $11.11(2)$ & $0(0)$ & $5.56(2)$ & $\chi^{2}=0.53(.467)$ \\
\hline \multirow[t]{2}{*}{$\begin{array}{l}\text { Phase - writing } \\
\text { dissertation or thesis }\end{array}$} & Yes & $11.11(2)$ & $27.78(5)$ & $19.44(7)$ & $\chi^{2}=0.71(.400)$ \\
\hline & & \multicolumn{3}{|c|}{ Mean \pm standard error (median) } & \\
\hline Factor & & Non-constellated group & Constellated group & General & $p$-value ${ }^{*}$ \\
\hline Age (years) & & $31.61 \pm 1.89(31)$ & $26.39 \pm 0.96(26)$ & $29.00 \pm 1.14(27)$ & .094 \\
\hline $\begin{array}{l}\text { Number of people in } \\
\text { household }\end{array}$ & & $2.29 \pm 0.51(2)$ & $1.89 \pm 0.27(2)$ & $2.09 \pm 0.28(2)$ & .815 \\
\hline UFU choice & & $8.33 \pm 0.33(8.5)$ & $7.83 \pm 0.47(8.5)$ & $8.08 \pm 0.29(8.5)$ & .739 \\
\hline Agronomy choice & & $8.56 \pm 0.42(9)$ & $7.61 \pm 0.44(7.5)$ & $8.08 \pm 0.31(9)$ & .710 \\
\hline Search line choice & & $8.33 \pm 0.42(9)$ & $8.06 \pm 0.73(9)$ & $8.19 \pm 0.42(9)$ & 1.000 \\
\hline Project choice & & $8.17 \pm 0.43(9)$ & $7.78 \pm 0.65(8)$ & $7.97 \pm 0.39(8.5)$ & .739 \\
\hline Advisor choice & & $8.29 \pm 0.54(9)$ & $8.29 \pm 0.55(8)$ & $8.29 \pm 0.38(8.5)$ & 1.000 \\
\hline Post graduation choice & & $8.35 \pm 0.28(8.5)$ & $7.93 \pm 0.42(8.2)$ & $8.14 \pm 0.25(8.2)$ & .504 \\
\hline Semester of the course & & $3.06 \pm 0.41(2)$ & $3.17 \pm 0.31(3)$ & $3.11 \pm 0.25(2)$ & .504 \\
\hline
\end{tabular}

Note. ${ }^{\#}$. Comparison between the group profiles based on the Qui-square test of independence $\left(\chi^{2}\right)$ and in the Exact Fisher test for the other variables (values without statistic). *. Comparison between the group profiles, based on the median independent test. 
The comfort scale to be evaluated, pre-constellation, showed lower values $($ mean $=5.31$, median $=6$, standard deviation $=$ 1.40 ; minimum value $=2$ and maximum $=7$ ), when compared to the scale values expected by students after the constellation $($ mean $=8.25$, median $=8.5$, standard deviation $=0.93$; minimum value $=6$ and maximum $=9)(Z=-3.57, p<.001)$. This means that all were expecting improvement after therapeutic intervention. This, in fact, happened, since after the constellation the average and the median of the comfort scale increased in relation to the values reported by the students at the beginning of the semester, before the constellation (mean $=6.94$, median $=7$, standard deviation $=1.86$; minimum value $=2$ and maximum $=9)(Z=-2.72, p=.038)$, although they were smaller than those expected by them $(\mathrm{Z}=-2.15, p$ $=.031)$.

The comfort scale was correlated with the domains of the WHOQOL-Bref (see Table 3). There was a positive correlation between the pre-constellation comfort scale and the comfort scale expected by the students $(r s=.536 ; p<.05)$, namely, the greater the comfort the students felt when being evaluated, the more comfort they desired and hoped to reach after the constellation. There was a negative correlation between the pre-constellation comfort scale and the health satisfaction in post-constellation $(r s=-.509, p<.05)$. The comfort scale expected by the students was positively correlated with the social domain in the pre-constellation ( $r s$ $=.521 ; p<.05)$. The comfort scale after the constellation was positively correlated with the psychological domain in the pre $(r s=.549 ; p<.05)$ and in the post constellation $(r s$ $=.494 ; p<.05)$ and with the environment domain in the pre-constellation $(r s=.522 ; p<.05)$.

The increase in the perception of quality of life, satisfaction with health, the physical domain and the social relations domain were not influenced by the constellation and the variables selected as predictors in the proposed multiple regression model. The participation in the constellation increased the deviations of the psychological domain (constant $=-3.75$, participation in the constellation $B i=8.843, p=.023$ ), and no other variable influenced these deviations. The constant of the model ( $B i$ ) was equal to 0.733 for the environment domain. This domain also had a positive influence from participation in the constellation ( $B i=6.709, p=.017)$, negative to having a scholarship $(B i=-7.972, p=.010)$ and positive to being in the phase of statistical analysis $(B i=6.588, p=$ .028).

Table 2. Mean difference in the scores of the WHOQOL-bref domains (end of the semester - beginning of the semester) of 36 students of the Postgraduate Program in Agronomy - UFU, 2017, 18 constellated and 18 non-constellated

\begin{tabular}{llllll}
\hline & \multicolumn{4}{c}{ Mean \pm standard error } \\
\hline Domain & Non-constellated group & $\boldsymbol{p}^{\#}$ & Constellated group & $\boldsymbol{p}^{\#}$ & $\boldsymbol{p}^{*}$ \\
\hline Perception of the QOL & $-0.11 \pm 0.14$ & .430 & $0.28 \pm 0.14$ & .051 & .052 \\
Satisfaction with health & $0.06 \pm 0.22$ & .805 & $0.38 \pm 0.26$ & .163 & .389 \\
Physical domain & $-4.89 \pm 4.01$ & .239 & $1.12 \pm 2.82$ & .640 & .209 \\
Psychological domain & $-3.75 \pm 2.59$ & .167 & $4.69 \pm 2.87$ & .071 & .023 \\
Social relations domain & $-0.46 \pm 4.44$ & .918 & $0.52 \pm 4.96$ & .758 & .770 \\
Environment domain & $0.87 \pm 1.90$ & .654 & $4.88 \pm 2.06$ & .016 & .120 \\
\hline
\end{tabular}

Note. ${ }^{\#}$. Probability for the Student $t$ test for one sample (each group was tested independently), assuming that the expected mean of the differences in the scores of the WHOQOL-bref domains was different from zero. ${ }^{*}$. Probability for the Student $t$ test for comparison between the means of the two groups.

Table 3. Spearman correlations for the evaluation scale and for the WHOQOL-bref domains, applied to 18 students of the Postgraduate Program in Agronomy - UFU, 2017, submitted to structural constellation

\begin{tabular}{lllllllllll}
\hline & ESPC & PostCS & & PQOL & SH & PhyD & PsyD & SRD & ED \\
\hline \multirow{2}{*}{ PreCS } & \multirow{2}{*}{$0.536^{*}$} & \multirow{2}{*}{0.021} & Pre & 0.000 & -0.251 & -0.070 & 0.126 & 0.178 & 0.150 \\
& & & Post & -0.144 & $-0.509^{*}$ & 0.070 & -0.091 & 0.151 & -0.243 \\
\multirow{2}{*}{ ESPC } & \multirow{2}{*}{1.000} & \multirow{2}{*}{0.175} & Pre & 0.076 & 0.106 & 0.007 & 0.300 & $0.521^{*}$ & -0.035 \\
& & & Post & 0.146 & -0.420 & 0.244 & 0.021 & 0.255 & -0.213 \\
\multirow{2}{*}{ PostCS } & \multirow{2}{*}{0.175} & \multirow{2}{*}{1.000} & Pre & 0.437 & 0.457 & 0.451 & $0.549^{*}$ & 0.425 & $0.522^{*}$ \\
& & & Post & 0.288 & 0.424 & 0.373 & $0.494^{*}$ & 0.470 & 0.433 \\
\hline
\end{tabular}

Note. PreCS: Pre-constellation scale, ESPC: Expected scale for the post-constellation, PostCS: Post-constellation scale; PQOL: Perception of Quality of Life, SH: Satisfaction with health, PhyD: Physical Domain, PsyD: Psychological Domain, SRD: Social Relations Domain, ED: Environment Domain; ${ }^{*} p<.01$ based on the Student $t$ test 


\section{Discussion}

Despite the difference in sample size, in the survey carried out by Faro, ${ }^{[2]}$ there was also a predominance of women, with a median age of 28 years, attending the third semester of postgraduate school. For the students who are attending the Master's degree, this represents the penultimate semester of the course, but for the Doctorate, that is less than half of the course. The predominance of women in the samples of postgraduates analyzed was also recorded by other authors ${ }^{[5,7,11,12]}$ and this, according to Faro, ${ }^{[2]}$ is associated with the increase in the number of women who finished their postgraduation in Brazil since 2004. "Women remain as a majority in the Brazilian postgraduation" was a headline at CAPES in March 2018 (http://www . capes .gov.br/sal a-de-imprensa/noticias/8787-mulheres-permane cem-como-maioria-na-pos-graduacao-brasileira). According to the article published by CAPES, 165,564 women had postgraduate titles or were enrolled in Masters and doctorate courses in 2016, while men totalled 138,462, with a difference of approximately $19 \%$.

From a systemic point of view, especially regarding the orders that guide life in groups, the balance between giving and receiving may have been the trigger for the behaviour described in the profile of the students of the Postgraduate Program in Agronomy from UFU. People who earn from life (scholarship students) became available to receive (they accepted the constellation). This is the principle that Hellinger et al. call a total exchange. ${ }^{[27]}$ According to the author, this donation and full reception is the core of relationships, because both sides become donors and receivers. The author also affirms that giving and receiving on a large scale brings a feeling of abundance and happiness. In the specific case of postgraduation, which brings in its trajectory the history that to become a researcher it is necessary to suffer, ${ }^{[36]}$ the exercise of this total exchange could alleviate the suffering of the students. The postgraduation system would only need to change its outlook on students, giving them conditions to enjoy some type of therapy, either individual or in group. General systemic exercises can relax the relationship between members of the academic community (students, technicians and teachers), and specific constellations can solve more complex cases, which would be a good alternative.

The improvement in the quality of life of the students after the constellation in relation to the psychological and environment domains reinforces the positive impact of a constellation in the life of a postgraduate student. The demands will continue to exist, but the way the students face them, as a test of their competences enhanced with the theoretical and practical classes and guidance pari passu of a competent professional (advisor), will be positive, because the students

Published by Sciedu Press will see that all are committed to the same goal. This is the total exchange, sensu Hellinger et al., ${ }^{[27]}$ to guarantee the status of the Postgraduate Program with the Research and Postgraduate Agencies. The Program offers physical infrastructure, technical information, materials and equipment for the development of the researcher and research and, on the other hand, the student who receives this gives the work produced in exchange, and the acquired competence will be passed ahead, to the new generations.

Another aspect that should be addressed in the environment domain and that interferes with the quality of life of a person is the environment at home. In the case of the postgraduate students who need to be focused on their work to meet deadlines with quality, any family disturbance, whether financial (even if they have a scholarship), health or relationship interferes in their performance. In this situation of difficulty or high stress, it becomes easier for the person to have one of the four basic behaviours that are fight, flee, faint or freeze. In this way, the student does not remain in the present so as not to suffer, and can enter into a type of trance, living the stressor as something present, even if the stress is not happening at that time. This causes the students to cease being productive. The fact that they need to stop focusing on their research to solve family problems becomes a threat to their survival as researchers. Facing threats to survival is a memory that is passed from generation to generation and produces patterns of cognitive, emotional and physiological behaviour, triggered during a difficulty. Thus, the trance can also be systemic, because the person accesses information from the past, becoming less available for the present moment. ${ }^{[37]}$ The constellation helps the person reconnect with the present moment, getting out of the family entanglements and traumas of the past.

In relation to the comfort scale to be evaluated, most students did not achieve the desired level of comfort, but they did move towards the established goal. This is the objective of the constellation, that is, to put the client (here, the student) in the flow of life. If the person remains in what psychodrama calls a "cultural reserve", that is, if they remain faithful to the extremely structured knowledge they bring with them, ${ }^{[38]}$ they will not give space to spontaneity and creativity which are essential to everything new, especially in the field of research.

The negative correlation between the pre-constellation comfort scale and the health satisfaction in post-constellation indicates that the greater the comfort felt when being evaluated, the more demand the students made themselves so as to stay within the level achieved throughout the semester, to the point that they became unhappy with their health. To main- 
tain a certain external quality standard, the students cease to take care of their personal needs to the point of negatively affecting their quality of life. This is a type of heteronomy where the rule to be followed is linked to another and not to one's personal consciousness. This is the infant and limited aspect of life itself, without the broader view of the adult that measures the consequences of their actions in the short, medium and long term.

The positive correlation between the comfort scale expected by the students and the social domain in the pre-constellation means that the more comfort they hoped to achieve with the constellation, the more well-connected socially they were at that time. This may indicate the willingness of the students to have exchange relations, as described by Hellinger et al. ${ }^{[27]}$

The positive correlation between the comfort scale after the constellation and the psychological domain in the pre and in the post constellation and with the environment domain in the pre-constellation show that the more psychological and socially adjusted to the environment the students were, the greater is their comfort level when being evaluated. It can also be assumed that the students who chose to participate in the constellation were willing to consider assessments as a natural process within the academic and scientific environment, with the help of therapy.

The results obtained with the multiple regression model shows that the constellation had a positive influence on the psychological and environment domains and that the most pleasurable phase for students was the time to analyze the data obtained.

As expected, after the conclusion of the work, the students' testimony presented in classroom at the end of the semester was that they began to look at the evaluation process with more self-confidence, which can improve their academic performance, both in the disciplines and in the execution of activities related to the research project and in the defence of their dissertations or theses. The improvement of academic performance is reflected in the fulfilment of deadlines. This represents an important factor for the Postgraduate Programs to maintain their concept received in the assessments performed by CAPES, the Organization responsible for Postgraduation in Brazil.

The fulfilment of deadlines in the postgraduate period ends up being one of the greatest stressors among the students, as reported by Faro, ${ }^{[2]}$ in more than 100 Brazilian Postgraduate Programs. The most worrying is that almost $50 \%$ of the students in the survey reported high to very high stress, resulting in losses of performance. As the author well emphasizes, this stressor creates the idea that study is intimately connected to suffering, which sustains the false belief that knowledge can only be achieved in the course of a martyrdom. It seems that the formation of researchers and psychological suffering are directly related, which shows that the growth of Brazilian science happens due to an enormous emotional exhaustion. ${ }^{[36]}$

In the approach of the constellations, this is linked to what is called belonging and this is related to three levels of consciousness - personal, collective and spiritual. ${ }^{[20,21,27]}$ Personal consciousness tunes the person with the expectations and demands of the group to which they belong or want to belong. To belong it is necessary to be in the same pattern in relation to the other components of the group, because the collective consciousness is blind. It needs everyone to perform in a certain way, even if this is in detriment to some members of the group. This consciousness is collective and is based on the family or group as a whole. That is why it is at the service of the collective survival of the group, even if for that some members have to be sacrificed. ${ }^{[20,27]}$ The collective consciousness does not look at the individual, but at the group as a whole and sees each member only as their function in the group.

It seems then that the personal consciousness informs that to be a researcher it is necessary to suffer. To be part of the group and a researcher, one must work to exhaustion. Whoever, at the end of the day or project is invigorated and happy, may not be taken seriously. Therefore, they will do everything to belong, even if that means dying in the social and psychological sense. First, they die in the family system and then in the underlying systems, as in the University, failing to express themselves and be successful in activities or else becoming physically ill. At this point the systemic therapist can ask their client (student or researcher) - What do you need to suffer for? What would it be like to be a master or doctoral student, performing all the work with a carefree attitude?

From a collective standpoint, the therapist can also ask questions related to the university system - Who suffered and was not recognized? Who needs to be seen and was not honoured? The suggestion that is made to mitigate this collective consciousness can be, for example, to build a gallery with photos of the Founders, Rectors, Coordinators, so that the next generations of researchers can know all the previous members who sustained the system and, who knows, so they can honour these previous members, living the university environment differently and with lightness. When the solution is found in a constellation, giving a place to those who were excluded (previous vilified generations), attributing to them the merits and demerits of their acts, those who come after, i.e., the descendants or successors, leave to the predeces- 
sors the guilt and the consequences of their acts, consciously withdrawing from the pathological dynamics in which the descendants were entangled. ${ }^{[29]}$ Thus, balance is achieved.

It is interesting to note that the principles included in the constellation (belonging, hierarchy and equilibrium) are the same as those presented by different authors adhering to the organic vision of the Universe. ${ }^{[39-43]}$ The ecological balance is the shared harmony and represents the key to ecological ethics. ${ }^{[40]}$ According to this view, the interest that each individual has for himself/herself reverberates at all levels, from cellular to macroscopic. At the same time, each individual needs the help of the group for his/her survival. In the balanced system, each party is responsible for itself, without taking more than necessary, and with this, each part contributes to the welfare of the whole. ${ }^{[40]}$ This is how Gaia (Earth) works as a healthy organism, in dynamic equilibrium, and differentiates itself from other lifeless planets, as we know it. ${ }^{[39,40]}$ If any imbalance happens, it self-organizes.

In the organic view of the Universe, regarded as the world of implicit or folded order, ${ }^{[44]}$ or as a Participatory Universe, ${ }^{[45]}$ the backdrop of all matter is the zero-point field (see the history of these discoveries in McTaggart ${ }^{[46]}$ ). This zero-point field is approached from antiquity and now is known by various denominations such as Akashic Field, ${ }^{[47]}$ Informed Field ${ }^{[48]}$ or Higgs field. ${ }^{[49,50]}$ The implication of this vision in the healing process was presented by several authors in the book edited by Ranal \& Amorim ${ }^{[51]}$ and by Amorim ${ }^{[52]}$ and the implications in the constellations were presented by Ranal. ${ }^{[53]}$ When Hellinger et al. ${ }^{[27]}$ affirms that consciousness is a group, the overlapping of concepts is noticed and we have their validation at all levels, from the cellular to the planetarium and, who knows, universal. In the vision of the microbiologist Margulis, ${ }^{[42]}$ there is no species more favoured than the other, because each organism takes care of its own life, growing until reproduction, under specific conditions and under certain selective pressures. The result of this is Gaia, the Earth as a mega-organism, and in this con- text, no individual and no species is more important than the other, because the most important is the life that manifests itself on the Planet, and biodiversity is an essential condition to Gaia's continuity.

The second important point that stands out in the present study is that the best quality of life of postgraduate students may reflect in an increase in the quality of the work produced, generating more publications in high-impact journals. This is the essential aspect required by the research funding agencies, because with the increase of high quality publications, Brazil can occupy a prominent position in the world rank of research and technology.

To make easier the understanding of the constellations dynamics we recommend Sparrer, ${ }^{[22]}$ Echegaray $^{[26]}$ and Hellinger. ${ }^{[54,55]}$ The authors present complete descriptions of several constellations, including schemes that show the movement of the representants.

\section{Conclusion}

Despite the small sample analyzed, this study is pioneering and points out that structural constellations exerts a positive effect on the postgraduate students, especially regarding the psychological factor and the environment.

\section{ACKNOWLEDGements}

To Dr. Denise Garcia de Santana, the Coordinator of the Postgraduate Program in Agronomy of the Universidade Federal de Uberlândia, to Dr. João Paulo Ribeiro-Oliveira and Tâmara Prado de Morais who allowed entry into classroom for data collection, to the students who agreed to participate in the project and to Roger Hutchings for the English review and important suggestions. Special thanks to the systemic therapists who participated as representatives in the constellations performed.

\section{CONFLICTS OF INTEREST Disclosure}

The authors declared no conflicts of interest.

\section{REFERENCES}

[1] Indjaian ML. Avaliação na pós-graduação stricto sensu: reflexões sobre a sua prática no Brasil. Seminário Internacional de Educação Superior 2014: formação e conhecimento [Evaluation in stricto sensu postgraduation: reflections on its practice in Brazil. International Seminar on Higher Education 2014: training and knowledge]. Electronic Anals. 2014. Available from: https://uniso.br/publicacoes/anais_eletronicos /2014/6_es_avaliacao/11.pdf. Portuguese.

[2] Faro A. Estresse e estressores na Pós-Graduação: estudo com Mestrandos e Doutorandos no Brasil [Stress and stressors in post- graduation: a study with Master's and Doctoral students in Brazil] Psicologia: Teoria e Pesquisa. 2013; 29(1): 51-60. https://doi. org/10.1590/S0102-37722013000100007. Portuguese.

[3] Valadares JL, Macedo AS, Alcântara VC, et al. 'Afinal, você também trabalha?' Reflexões sobre o não trabalho no ambiente da pósgraduação em Administração ['After all, do you work too?' Reflections on not working in the postgraduate environment in Administration]. In: XXXVIII Encontro da ANPAD - Associação Nacional de Pós-Graduação e Pesquisa em Administração. Anais. https://doi.org/10.21714/tpa.v4i2.20817. Portuguese.

[4] Rezende MS, Miranda GJ, Pereira JM, et al. Stress e desempenho 
acadêmico na pós-graduação stricto sensu em ciências contábeis no Brasil [Stress and academic performance in the stricto sensu postgraduation in Accounting Sciences in Brazil]. Arquivos Analíticos de Políticas Educativas. 2017; 25(96). https ://doi .org/10.145 07/epaa. 25.2931. Portuguese.

[5] Santos AF, Alves Júnior A. Estresse e estratégias de enfrentamento em mestrandos de Ciências da Saúde [Stress and coping strategies of Master's Health Sciences students]. Psicologia: Reflexão e Crítica. 2007; 20(1): 104-113. https://doi.org/10.1590/S0102-797 22007000100014. Portuguese.

[6] Malagris LEN, Suassuna ATR, Bezerra DV, et al. Níveis de estresse e características sociobiográficas de alunos de pós-graduação [Levels of stress and sociobiographic characters of postgraduate students]. Psicologia em Revista. 2009; 15(1): 184-203. https ://doi.org/ 10.5752/P. 1678-9563.2009v15n2p184. Portuguese.

[7] Andrade EF, Vasconcelos ACN, Nakagaki KYR, et al. Alta prevalência de estresse em pós-graduandos de ciências veterinárias [High prevalence of stress in Veterinary Sciences postgraduate students]. Medicina Veterinária. 2013; 7(2): 45-52. Available from: https://www.researchgate.net/publication/274390025 _Alta_prevalencia_de_estresse_em_pos-graduandos_de _ciencias_veterinarias. Portuguese.

[8] Gozdziejewski AS, Cardoso ES. Avaliação de estresse em alunas de pós-graduação em Enfermagem [Stress assessment in Nursing postgraduate students]. IX Congresso Nacional de Educação e III Encontro Sul Brasileiro de Psicopedagogia. 2009. Available from: http://educere.bruc.com.br/arquivo/pdf2009/ 3220_2215.pdf. Portuguese.

[9] Selye H. History and present status of the stress concept. In: Goldberger L, Breznitz S. (eds.). Handbook of stress: theoretical and clinical aspects. Nova York: Free Press; 1984. 7-17 p.

[10] Lipp MN. Manual do inventário de sintomas de stress para adultos de Lipp [Lipp adult stress symptoms inventory manual]. São Paulo: Casa do Psicólogo; 2000. Portuguese.

[11] Ferreira JS, Oliveira LA, Godinho RLP, et al. Alunos da pósgraduação em enfermagem e o nível de estresse [Nursing postgraduate students and stress level]. Revista Pró-UniverSUS. 2016; 7(3): 2025. Available from: http://editora.universidadedevassou ras.edu.br/index.php/RPU/article/view/659. Portuguese.

[12] Galdino MJQ, Martins JT, Haddad MCFL, et al. Síndrome de Burnout entre mestrandos e doutorandos em Enfermagem [Burnout syndrome among Master's and Doctoral students in Nursing]. Acta Paulista de Enfermagem. 2016; 29(1): 100-106. https ://doi.org/10.1590/ 1982-0194201600014. Portuguese.

[13] Escobar MAR, Verdinelli MA. Percepção do discente sobre produtividade científica em um programa de pós-graduação stricto sensu [Student's perception of scientific productivity in a stricto sensu postgraduate program]. X Colóquio Internacional sobre Gestión Universitaria en América Del Sur: Balance y Prospectiva de la Educación Superior en el marco de los bicentenarios de América del Sur. Mar Del Plata. 2010. Available from: https://repositorio.ufsc.b $r /$ handle/123456789/97083. Portuguese.

[14] Moura LRNI, Charão-Brito L, Lopes LFD. Vigor, dedicação, absorção: uma análise da percepção de profissionais pós-graduandos sobre engajamento no trabalho [Vigor, dedication, absorption: an analysis of postgraduate professionals' perception on commitment to work]. Revista CESUMAR. 2017; 22(2): 229-245. https://doi org/10.17765/1516-2664.2017v22n2p229-245. Portuguese.

[15] Universidade Federal de Uberlândia. Resolução n07/99, do Conselho Universitário. Autoriza a implantação do Programa de PósGraduação em Agronomia, em níveis de Mestrado e Doutorado, nas áreas de concentração em Fitopatologia, Fitotecnia e Solos
[Federal University of Uberlândia. University Council Resolution $\mathrm{n}^{\circ} 07 / 99$. Authorizes the implementation of the Postgraduation Program in Agronomy, Masters and Doctorate levels in the concentration areas in Phytopathology, Phytotechny and Soil]. 1999. Available from: http://www.reitoria.ufu.br/Resolucoes/ata CONSUN-1999-7.pdf. Portuguese.

[16] Federizzi ALC, Vitorino ACT, Lopes SA. Relatório de Avaliação: Ciências Agrárias [Evaluation report: Agrarian Sciences]. Avaliação Quadrienal. Ministério da Educação, Coordenação de Aperfeiçoamento de Pessoal de Nível Superior, Diretoria de Avaliação. 2017. 43 p. Available from: http: //avaliacaoquadrienal . capes.gov.br/resulta do-da-avaliacao-quadrienal-2017-2/CIENCIAS\%20AGRA RIAS $\% 20$ I_relat $\%$ C3 $\%$ B3rio $\% 20$ de $\% 20$ avalia $\%$ C3 $\%$ A $7 \%$ C3 $\%$ A 3o_quadrienal\%202017_final.pdf?attredirects=0\&d=1. Portuguese.

[17] Franke-Bryson U. O rio nunca olha para trás [The river never looks back]. São Paulo: Editora Conexão Sistêmica; 2013. Portuguese.

[18] Hellinger B, Hövel G. Constelações familiares: o reconhecimento das ordens do amor [Family constellations: recognition of the orders of love]. Trad. Tironi EG, Jinno-Spelter T. São Paulo: Editora Cultrix; 2007. Portuguese.

[19] Hellinger B. A fonte não precisa perguntar pelo caminho: um livro de consulta [The source does not need to ask by the way: a query book]. Trad. Tironi EG, Jinno-Spelter T. 3 ed. Goiânia: Editora Atman; 2012a. Portuguese.

[20] Hellinger B. O amor do espírito na Hellinger Sciencia [The love of the Spirit in the Hellinger Sciencia]. Trad. Jinno-Spelter T, Richter L, Richter F. 2 ed. atualizada de acordo com a revisão ortográfica de 2009. Goiânia: Editora Atman; 2012b. Portuguese.

[21] Schneider JR. A prática das constelações familiares: bases e procedimentos [The practice of family constellations: bases and procedures] Trad. Queiroz NA. 2 ${ }^{\mathrm{a}}$ ed. Goiânia: Editora Atman; 2013. Portuguese.

[22] Sparrer I. Enfoque de solución en constelaciones sistémicas [Solution approach to systemic constellations]. Trad. Beniers E. México: Editorial Herder; 2012. Spanish.

[23] Lipton BH. A biologia da crença: ciência e espiritualidade na mesma sintonia; o poder da consciência sobre a matéria e os milagres [The biology of bilief: science and spirituality in the same tune; the power of consciousness over matter and miracles]. Trad. Vick Y. São Paulo: Butterfly Editora; 2007. Portuguese.

[24] Jablonka E, Raz G. Transgenerational epigenetic inheritance: prevalence, mechanisms, and implications for the study of heredity and evolution. The Quarterly Review of Biology. 2009; 84(2): 131-176. PMid:19606595. https : //doi.org/10.1086/598822

[25] Faria Junior AJP, Neris ARMT, Oliveira IP. Epigenética e psicologia: uma possibilidade de encontro entre o social e o biológico [Epigenetics and Psychology: a possibility of meeting between the social and the biological]. Revista Internacional em Língua Portuguesa, Ciências da Saúde e Tecnologia. 2018; (34): 15-36. https : //doi .org/ 10.31492/2184-2043. RILP2018.34/pp. 15-36. Portuguese.

[26] Echegaray G. Para compreender las constelaciones organizacionales [To understand the organizational constellations]. 5 reimpressão. Navarra: Editorial Verbo divino; 2015. Spanish.

[27] Hellinger B, Weber G, Beaumont H. A simetria oculta do amor: porque o amor faz os relacionamentos darem certo [The hidden symmetry of love: because love makes relationships work]. Trad. Sousa GCC. São Paulo: Editora Cultrix; 1998. Portuguese.

[28] Hellinger B. Histórias de amor [Love stories]. Trad. Richter L, Richter F. 2 ed. Goiânia: Editora Atman; 2011. Portuguese.

[29] Hellinger B, Hövel G. Um lugar para os excluídos: conversas sobre os caminhos de uma vida [A place for the excluded: conversations 
about the paths of a life]. Trad. Queiroz NA. 2 ed. Goiânia: Editora Atman; 2010. Portuguese.

[30] Brasil. 2018. Ministério da Saúde. Portaria n 702 , de 21 de março de 2018. Altera a Portaria de Consolidação $n^{\circ} 2 / \mathrm{GM} / \mathrm{MS}$, de 28 de setembro de 2017, para incluir novas práticas na Política Nacional de Práticas Integrativas e Complementares - PNPIC. Diário Oficial da União [Brazil 2018. Health Ministry. Ordinance $n^{\circ} 702,21$ March 2018. Alters the Consolidation Ordinance ${ }^{\circ}$ 2/GM/MS, 28 September 2017, to include new practices in the National Policy of Integrative and Complementary Practices - PNPIC. Official Gazette of the Union]. 22 Mar 2018. Available from: http://bvsms . saude .gov.br/bvs/s audelegis/gm/2018/prt0702_22_03_2018.html. Portuguese.

[31] WHO. WHOQOL-bref Introduction, administration, scoring and generic version of the assessment. Field Trial Version. Programme on Mental Health. World Health Organization. Geneva. 1996. Available from: http://www.who.int/mental_health/media/en /76.pdf

[32] Fleck MPA, Louzada S, Xavier M, et al. Aplicação da versão em português do instrumento abreviado de avaliação da qualidade de vida "WHOQOL-bref" [Application of the Portuguese version of the abbreviated instrument for assessing quality of life "WHOQOL-bref"]. Revista de Saúde Pública. 2000; 34(2): 178-183. PMid:10881154. https://doi.org/10.1590/S0034-89102000000200012. Portuguese.

[33] WHO. Programme on mental health: WHOQOL user manual. Division of Mental Health and Prevention of Substance Abuse. World Health Organization. 2012 revision. Available from: http://www . who.int/iris/handle/10665/77932

[34] Fleck MPA. WHOQOL - abbreviated. Versão em Português [Portuguese version]. Programa de Saúde Mental. Organização Mundial da Saúde. Genebra. s.d. Available from: http://www.brasilei rosnomundo.itamaraty.gov.br/temas-sociais/questio narios-socio-economicos/programa-de-saude-mental. Portuguese.

[35] Mendes-Rodrigues C, Ranal MA, Carvalho DVP. Postgraduate students: an alert about quality of life. World Journal of Education. 2019; 9(1): 135-144. https://doi.org/10.5430/wje.v9n1p135

[36] Louzada RCR, Silva Filho JF. Formação do pesquisador e sofrimento mental: um estudo de caso [Researcher training and mental distress: a case study]. Psicologia em Estudo. 2005; 10(3): 451461. https://doi.org/10.1590/S1413-73722005000300013. Portuguese.

[37] Bryson T, Franke-Bryson U. Trauma, transe e transformação: o poder da presença na prática [Trauma, trance and transformation: the power of presence in systemic practice]. São Paulo: Editora Conexão Sistêmica; s.d. Portuguese.

[38] Fonseca Filho JS. Psicodrama da loucura: correlações entre Buber e Moreno [Psychodrama of madness: correlations between Buber and Moreno]. São Paulo: Editora Ágora; 1980. Portuguese.

[39] Lovelock J. As eras de Gaia: a biografia da nossa Terra viva [The eras of Gaia: the biography of our living Earth]. Trad. Sidou B. Rio de Janeiro: Editora Campus Ltda.; 1991. Portuguese.

[40] Sahtouris E. Gaia: do caos aos cosmos [Gaia: from chaos to cosmos]. Trad. Natale LMU. São Paulo: Editora Interação; 1991. Portuguese.
[41] Capra F. A teia da vida: uma nova compreensão científica dos sistemas vivos [The web of life: a new scientific understanding of living systems]. Trad. Eichemberg NR. São Paulo: Editora Cultrix; 1996. Portuguese.

[42] Margulis L. O planeta simbiótico: uma nova perspectiva da evolução [The symbiotic planet: a new perspective of evolution]. Trad. Neves L. Rio de Janeiro: Editora Rocco; 2001. Portuguese.

[43] Capra F. As conexões ocultas: ciência para uma vida sustentável [The hidden connections: science for a sustainable life]. Trad. Cipolla MB São Paulo: Editora Cultrix; 2002. Portuguese.

[44] Bohm DA. A totalidade e a ordem implicada: uma nova percepção da realidade [The totality and the implied order: a new perception of reality]. 12. ed. Trad. Silva M C. São Paulo: Editora Cultrix; 2001. Portuguese.

[45] Capra F. O tao da física: um paralelo entre a física moderna e o misticismo oriental [The tao of physics: a parallel between modern physics and Oriental mysticism]. Trad. Dias JF. São Paulo: Editora Cultrix. 1983. Portuguese.

[46] McTaggart L. O campo: em busca da força secreta do universo [The field: in search of the secret force of the Universe]. Trad. Duarte CG. Rio de Janeiro: Editora Rocco; 2008. Portuguese.

[47] Laszlo E. A ciência e o campo akáshico: uma teoria integral de tudo [Science and the Akashic field: an integral theory of everything] Trad. Eichemberg AT, Eichemberg NR. São Paulo: Editora Cultrix; 2008. Portuguese.

[48] Citro M. O código básico do Universo: a ciência dos mundos invisíveis na física, na medicina e na espiritualidade [The basic code of the Universe: the science of invisible worlds in physics, medicine and spirituality]. Trad. Moura Neto H, Argel M. São Paulo: Editora Cultrix; 2014. Portuguese.

[49] Witze A. Higgs boson fills last gap in list of basic particles. Science News. 2012; 182(2): 5-6. https ://doi .org/10.1002/scin. 559 1820203

[50] Rezende R. A partícula de Deus [The particle of God]. Superinteressante. Edição 301. 2012. Available from: https://super.abril. com.br/ciencia/a-particula-de-deus/. Portuguese.

[51] Ranal MA, Amorim M. (Org.). BioFAO na agricultura: recuperação da defesa natural das plantas [BioFAO in Agriculture: natural plant defense recovery]. Rio de Janeiro: Bonecker; 2017. Portuguese.

[52] Amorim M. Biofao: uma medicina para um novo tempo [Biofao: a medicine for a new time]. Rio de Janeiro: Bonecker Editora; 2018. Portuguese.

[53] Ranal MA. Campo de ressonância sistêmica: fruto da imaginação ou realidade [Systemic resonance field: fruit of imagination or reality?] Uberlândia: GW Publicações; 2017. Portuguese.

[54] Hellinger B. Ordens do amor: um guia para o trabalho com constelações familiares [Orders of love: a guide to work with family constellations]. Trad. Queiroz NA. São Paulo: Editora Cultrix; 2007. Portuguese.

[55] Hellinger B. Ordens da ajuda: um livro de treinamento [Help orders: a training book]. 3 edição. Trad. Jinno-Spelter T. Editora Atman; 2013. Portuguese. 